\title{
Effect Of Constraints On Perceived Business Success Of Rural Entrepreneurial Activities: A Case Of Two Rural Municipalities
}

Albert Tchey Agbenyegah, Durban University of Technology, South Africa

\begin{abstract}
This study aims to evaluate the effect of selected entrepreneurial constraints on the perceived business success of small businesses. In this study the dependent variable, perceived business success is measured by two variables; business growth and existence of human capital. A 7 Likert scale structured questionnaires anchored on "1" strongly disagree and "7" strongly agree is used to source data from entrepreneurs. The convenience and snowball technique were used to source 300 entrepreneurs from the target population for data. Reliability of the measuring instrument was possible through the Cronbach alpha while the questionnaire was piloted for conceptual realities. In this study, the precise and individual constraints were operationalized as independent variables. Relationships between the independent variables and the perceived business success as dependent variable were investigated through multiple linear regression analysis. The outcomes of the study resolved that precise and individual constraints impact negatively on the perceived business success of small businesses and entrepreneurial activities. The findings further revealed adverse links between the independent and the dependent variable known as the perceived business success.
\end{abstract}

Keywords: Perceived Business Success; Precise and Individual Constraints; Entrepreneur; Frances Baard; John Taolo Gaetsewe Municipalities

\section{INTRODUCTION}

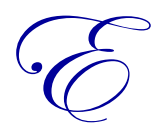

ntrepreneurial activity is a universal concept that is very instrumental in rural development (Baumgartner, Schulz \& Seidi, 2013). Globally, researchers view entrepreneurial activities as the most socio-economical tool of development (Karimi, Chizari, Biemans \& Mulder, 2010). It is therefore generally believed that entrepreneurial activity flourishes provided the entrepreneur makes successful business decision (Rwigema \& Venter, 2008).

In spite of these benefits, several entrepreneurship literature highlights multitude of constraints such as lack of financial support to managerial inabilities (Bates, Jackson, Johnson 2007; Ooghe \& De Prijcker, 2008; Wenneberg, Wiklund, Detienne \& Cardon, 2010; Fatoki \& Chindoga, 2011). These and other constraints create severe restrictions to rural entrepreneurial activities (REA) in South Africa (Cardon, Stevens \& Potter, 2009; Townsend, Busenitz \& Arthurs, 2010). Entrepreneurial activities in South Africa has declined over the years in comparison to other developing countries. According to the Global Entrepreneurial Monitor (GEM) report, South African Total EarlyStage Entrepreneurial Activity (TEA) now stands at 5.9\% low in contrast to the average of $12 \%$ of all efficiencydriven global economies (Herrington, Kew \& Kew, 2010). Given these constraints, significant to research into South African REA. Entrepreneurial activities in this study mainly referred to small business operations. REA is faced with countless constraints such as funding, time and long market distances (Beer, 2004; Stathopoulos, Psaltopoulous \& Skurus, 2004). Realities are that REA experiences decline in population density, ageing community members, distant marketing environment and limited technology advances (Investment Climate Survey, 2004; OECD, 2006; South Africa Information, 2010). Besides, rural communities are often very far from urban localities where customers, suppliers, financiers, advisers and other support agencies are centralized. In addition, REA is marred by strict 
regulatory framework, high start-up costs and lack of enough collateral to access funds (Fonseca, Michand \& Sopraseuth, 2007; Nichter \& Goldmark, 2009; Ardagna \& Lusardi, 2009).

Rural entrepreneurship experience high transportation costs in contrast to urban areas (Stathopoulou et al., 2004). As Skuras, Meccheri, Moreira, Rosell and Stathopoulos (2005) put it, rural areas are largely faced with precise and individual constraints due to decrease in population as communities continue to search for job opportunities in urban areas. This according to Du Plessis and Smit (2004), implies that individuals who resides in rural areas grow older with limited chances of job securities. Even in the developed world empirical evidence shows that entrepreneurship is confronted with fierce constraints of complex trade regulations because of poor product qualities (Matlay \& Carey, 2007; Lind, 2009; Kwong, Thompson \& Jones-Evans, 2012). Parker (2007) asserts that entrepreneurship and small business operations is confronted with various aspects of excessive business rules high costs to entrepreneurs. A situation that bears similarities in developing countries such as South Africa where little is known of entrepreneurial research (Lan \& Wu, 2010; Nabi \& Linan, 2011; Ahmad \& Xavier, 2012).

This paper is organized as follows: Initially the problem statement and the study objectives are stated. The next section takes into account, the theory that provided guidance to the study proposition. Thereafter, the precise and individual constraints are outlined. The research methodology of this study is provided and followed by discussions and conclusions. Based on the study outcomes, recommendations were thoughtfully laid out.

\section{OBJECTIVES}

The objective of the study was to evaluate the effect of precise and individual constraints on PBS. Furthermore, the aim was twofold; namely to test the hypotheses that precise and individual effect on PBS. Furthermore, the study seeks to determine the relationships between precise and individual on the PBS.

\section{OPERATIONALISATION OF THE STUDY VARIABLES}

Small businesses in this study are defined as businesses that employs less than 50 full-time paid employees (The South African National Small Business Act 1996 as amended 2004). The concepts of entrepreneurial activity and small businesses are providers of economic growth and development (Karpak \& Topcy, 2010). Entrepreneurial activity is operationalized as human actions directed at creating economic values through new business opportunities. From these definitions, it can be stated that the twin concepts of entrepreneurial activities and small businesses are used interchangeably throughout the study. For the purpose of this study, entrepreneurs are defined as individuals who seeks opportunities, gathers resources in the midst of risky and uneasy business climate couple with necessary actions to ensure successful operations (Makhbul \& Hasun, 2011). Equally, it is critical to operationalized Individual and precise constraints. Individual constraints are defined in the study as constraints that influence entrepreneurs during daily operations of small businesses and entrepreneurial activities. On the other hand, precise constraints are defined as particular constraints that impact directly on small business operations and entrepreneurial activities within the research areas. Few of these constraints are shown in the conceptual framework below. PBS is defined in the study as business growth due to the existence of EHC. The study further elaborates on what constitute business growth. These include increase in customer-base, good business image, increase in profit margin among others. EHC according to the researcher is operationalized as employees are valuable business assets, improvement in employees' morale, policies of employees' retention.

\section{THE CONCEPTUAL FRAMEWORK}

Figure 1 below depicts three variables namely the PBS, precise and individual constraints which were designed as an investigative tool to determine their effect on PBS. The framework posits that precise and individual constraints (independent variables) impact on PBS (dependent variable). 
Figure 1. Conceptual framework: Independent and dependent variables

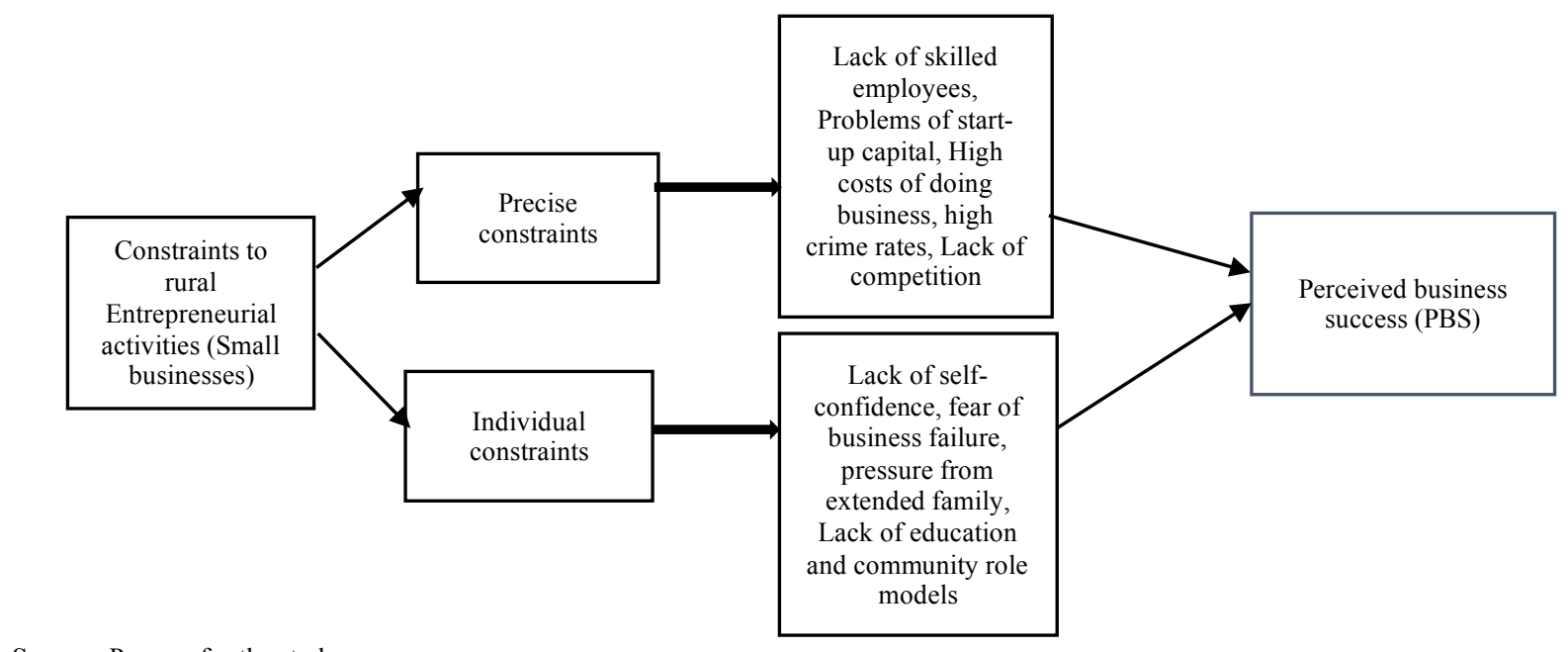

Source: Prepare for the study

\section{THEORETICAL FRAMEWORK}

Small businesses are known to play significant role in national growth and generates more revenue (Kongolo, 2010). Entrepreneurial activities and small businesses are acknowledged to enhanced economic growth, create country-wide. Constraints are growing common sights as one pursue entrepreneurial activities. In South Africa entrepreneurial activities face severe constraints (Herrington, J. Kew \& P. Kew, 2010). The Small business sector is largely documented to bear the brand of numerous constraints. Constraints such as travelling long hours to market products and inefficient business skills among others (Cant, Gerber, Nel \& Kotze, 2012). Besides, several studies confirmed that contributions by small business have positively impact on social and economic lives of communities; establish an enhanced social welfare systems, job opportunities and stabilizes the market environment (Fatoki \& Chindoga, 2011). Others are of the view that contributions by the small business sectors has positive socio-economic effect on economic prosperities nation-wide (Masalira \& Msweli, 2013; Ackah \& Vuvor, 2011). Aside these benefits, existing studies pointed that roughly $40 \%$ of new business creations are unable to survive for the first year of operations, about $60 \%$ of these entrepreneurial activities are unable to endure the harsh realities of operating small businesses in the second year and $90 \%$ during the first 10 years of the business activities (Bowler, Dawood \& Page, 2007). In rural communities, entrepreneurial activities are unable to exhibit maximum growth due to constraints. For instance, scientific studies alluded to the fact that constraints such as weakening financial markets, and unreliable energy sources is of utmost concern (Hatega, 2007; Kauffmann, 2005; IFC, 2006).

\section{Perceived Business Success}

Business success lacks generally accepted definition due to its complex nature (Rogoff, Lee \& Suh, 2004). For example, in developing countries it is unusual to determine successful business activities (Rodriguez, 2009). It was further argued that firm growth is used as a significant yardstick to business growth (Davidsson, Steffens \& Fitzsimmons, 2009). Other scientific literature indicated that business success entails highly gainful entrepreneurs' tasks to grow existing ventures (Abdul, Omar \& Yee et al., 2012). Furthermore, business success is defined in other field of study differently. Within the accounting field of studies, profitability is applied as a measurement of business success (Xu \& Van der Heijden, 2005). Several business management literature refers to business success as firm performance (Alam, Jani \& Omar, 2011). Simply stated, variables of business duration, business survival rates and at least three years' business operations are applied to test business success (Taomina \& Lao, 2007; Van Praag, 2003). PBS as used in this study is the dependent variable (DV). The future of global business depends on the general growth rates of successful economic activities which are highly dependent on successful businesses (Dyllick \& Hockerts, 2002). Business success is attributed to factors such as psychological, skillful and competencies, managerial training, favourable business conditions and business knowledge (Hussain \& Windsperger, 2010; Benzing, Chu \& Kara, 2009). 
The most common definition of what constitutes business success has been linked to firm growth (Bigsten \& Gebreeyesus, 2007; Mead \& Liedholm, 1998. PBS as used in this study is evaluated by several related indicators namely: highly committed entrepreneurs for a successful businesses, employees are regarded as business assets, the employees and entrepreneurs' morale shows improvement, over the years small businesses experience customer growth, growth in business image, employees continue to work in the present businesses, significant increases in profit margins, high rate of employees' retention over the years, growth in stock and extension of services, small businesses experience high employee growth rate and the businesses are able to open more and add improvement to branches. Based on the above argument, the following hypotheses are formulated to be statistically tested:

Hypothesis 1: There is significant relationship between difficult business environment, lack of support and lack of skills and EHC.

Hypothesis 2: There is significant relationship between difficult business environment, lack of support and lack of skills and small business growth.

\section{Precise and Individual Constraints}

Precise and individual constraints are explained and applied in the study as independent variables. Several empirical evidences demonstrated that these constraints negatively effect on entrepreneurial and small business success (Gill \& Biger, 2012; Ishak, Omar \& Ahmad, 2012; Silverman \& Patterson, 2011; Blau, 2009). The current study is structured to consider the precise and individual to evaluate their effect on the PBS and EHC. Numerous empirical studies across the developing world outline entrepreneurial activities and small businesses are faced with mounting constraints (Kwong et al, 2012). These constraints include high unemployment, dwindling in income levels and inactive rural economic activities among others. Thus, creating significant negative effect on rural communities and entrepreneurship development (Faraji et al., 2011).

Despite their global importance and contributions to economic growth, small businesses experience drawbacks such as poor funding, incompetent managerial skills, improper education and training and limited business facilities (Martin \& Staines, 2008; Ehlers \& Lozenby, 2007). Entrepreneurial activities and small businesses are constraint by market entry barriers, negative image, burdensome and strict regulatory measures, excessive start-up costs, inadequate managerial and lack of training skills due to dysfunctional institutions (Abor \& Quartey, 2010; Ardagna \& Lusardi, 2009). Bosma, Acs, Autio, Condurus \& Levie, 2009) add that the regulations of protective employment status creates deeper miseries of entrepreneurship and small business opportunities country-wide.

Entrepreneurs of small businesses are unable to draw skillful employees to become more productive (Timm, 2011; Ngassam, Kandie, Nkaelang \& Modiba, 2009). Gem (2010) add that business regulations are to be blamed for the growing small businesses constraints. For example, Ahmad and Xavier (2012) indicated that macro-environmental forces of lack of financial assistance, lack of proper regulatory system, sub-standard educational structures and absence of entrepreneurial training poses severe hardships to entrepreneurs. Besides, scientific evidence has shown that South African financial institutions are hesitant to provide financial backing to entrepreneurs in townships (Woodward, Rolfe, Ligthelm \& Gruimaraes, 2011). Other scientific evidence adds that entrepreneurial activities and small business operations are constraint because of financial support (Fatoki \& Van Aardt Smit, 2011). Based on the above discussions the following hypotheses are to be tested using statistical method:

Hypothesis 3: There is significant relationship between individual constraints and PBS.

Hypothesis 4: There is significant relationship between individual constraints and EHC.

\section{RESEARCH METHODOLOGY}

\section{Research Approach}

Quantitative approach is used in this study to understand the various relationships between variables to explain, predict and for the purposes of controlling the extant phenomena. To collect primary data for this study, structured 
questionnaires were applied (Harrison \& Reilly, 2011). This was preceded by data analysis through the explanatory factor analysis (EFA) and the multiple linear regressions. This approach is deemed appropriate since the study aimed at collecting enough information not only to find solutions to the survey questions but also to formulate hypotheses.

\section{Measuring Instrument}

A total of 35 items were sub-divided into two sections; 12 statements measured PBS as the dependent variable. Measurement were specifically based on individual sections of the precise and individual constraints. Entrepreneurs of small businesses who were selected to participate in the study were asked to indicate the extent of each statement by indicting on a 7 Likert-type questionnaire. Options of the questions ranges from "1" strongly disagree to "7" strongly agree. In order to amend participants' opinions in the future, the measuring instrument was also designed to collect biographical data of entrepreneurs. Entrepreneurs of small businesses were further asked to indicate their age, gender, race groups, managerial skills levels and educational qualifications.

\section{Research Participants}

The target population of the study was all entrepreneurs of small businesses from two study areas of Frances Baard and John Taolo Gaetsewe district municipalities in the Northern Cape Province. Prior to the final selection, participants were screened for two reasons. Initially, to determine entrepreneurs who had been operating small businesses for at least five years within the study areas. Also, that the small businesses employed according to the employment headcount as indicated in the National Small Business Act, 1996 as amended in 2004. From the target population, few entrepreneurs were selected through the convenience and snowball techniques (Blumberg, Cooper \& Schindler, 2011; Cant et al., 2012).

\section{Research Procedure}

The procedure followed during this study include the application of a 7 Likert-type questionnaire to gather data from entrepreneurs. A trained field researcher acted as the main contact person to assist the entrepreneurs by explaining questions where necessary. At the same time, care was taken not to mislead the entrepreneurs in providing answers. In addition, the field researcher was tasked to check the questionnaires for errors at the time of collecting them from entrepreneurs. Throughout the study, key procedures such as anonymity of participants and the voluntary completion of the questions were paramount. In total 300 questionnaires were distributed; only 282 usable questionnaires were returned to be analysed with a high response rate of $48.6 \%$.

\section{Statistical Analysis}

Research data for this study was analysed by means of a Statistica (Statsoft, Inc 2010). Besides, EFA was applied during the primary stages of the analysis processes to determine the construct validity of the questionnaires. The Cronbach alpha coefficient was used as reliability assessment to ascertain conceptual clarity of the measuring instrument. More analysis was possible through the multiple linear regression in addition to other analytical tools to understand the exact relationship between the dependent and independent variables.

\section{RESULTS AND DISCUSSION}

\section{Demographic Profile of Entrepreneurs}

Entrepreneurs of small businesses took part in this study from two study areas as alluded to earlier in the study. Majority (40\%) of the entrepreneurs were aged between 30-39 years. This was followed by $(33 \%)$ within the age groups of 40-49 years while the third largest group were 50 to 59 years. In total, these groups accounted for $86 \%$ of entrepreneurs who participated in the study. Male participants were $63 \%$ in contrast to $35 \%$ female participants. Out of the total participants, $52 \%$ were married while $39 \%$ were unmarried. Regarding academic qualifications, only $23 \%$ had matric education, $18 \%$ had diploma and certificates qualifications. Only $7 \%$ of entrepreneurs achieved a university degree. 


\section{Construct Validity and Measuring Instrument}

This study aimed to ascertain relationships between variables as stated. Multiple regression analysis was chosen as the measurement tool. Prior to conducting the multiple regression analysis, the loading of each factor must be done (Hair, Black, Anderson \& Tatham, 2006). Empirical data was split into two models namely the dependent and independent variables to conduct the EFA. For the purposes of identifying the exact factor for extraction from the two models; the study computed percentages of variances for every factor loadings. The Oblimin rotation was done for the first model, the dependent variable on the principal component of the EFA. In addition, it was decided to understand the significance of the correct data for analysis through the Bartlett's Test of Sphericity (BTS) and the Kaiser-Meyer Olkin (KMO) measures of sampling adequacy (Gurbuz \& Aykol, 2009). The PBS (dependent variable) yielded a sample adequacy of 0.926 whereas the BTS generated a lesser $p$-value $=0.0001$ with correlations patterns that was compatible. Thus, creating a reliable factor analysis for the study (Field, 2009).

As discussed elsewhere in the study PBS is defined as business growth and the existence of human capital (EHC). For the purpose of this study, the researcher defined Business growth as: major increase in customer-base, good business image, increase in profit margin, increase in stock-turnover, additional business expansion and other improvement initiatives. Likewise, this study classified $\boldsymbol{E H C}$ as: enough pledge by employees and entrepreneurs, employees are valuable business assets, morale improvement of employees and entrepreneurs, good employees' retention policies, unwillingness of employees to work for other businesses and more employment avenues offered to employees.

Other measurement tools including the Kaiser's Criterion was applied to determine the number of factors for extraction and to retain the factors with eigenvalues that are greater than one (Field, 2009). All the 12 items as shown in the questionnaire revealed adequate discriminant validity by loading sufficiently. However, factor loadings for more than 0.35 were considered significant (Field, 2009). Table 1 below illustrates the factor matrix consisting of 12 items used to measure PBS (dependent variable). These items were in sections of two factors namely Business growth and $\boldsymbol{E H C}$. From the table, the 12 items were loaded significantly on to two factors that showed values greater than 0.35 . Decision was made by the researcher to clarify only the factors that yielded the highest loading to avoid exclusion. A correlation matrix was computed for the two dependent variables which showed a correlation value of 0.568 . According to the value it became eminent that oblique rotation should have been applied (Field, 2009; Ellis \& Steyn, 2006).

Table 1. Oblimin rotated factor matrix: Dependent variable ${ }^{(1)}$

\begin{tabular}{|c|c|c|}
\hline Items $^{(2)}$ & $\begin{array}{c}\text { Factor } 1 \\
\text { Existence of human capital }\end{array}$ & $\begin{array}{c}\text { Factor } 2 \\
\text { Business growth }\end{array}$ \\
\hline Success 1 & 0.923 & -0.115 \\
\hline Success 2 & 0.910 & -0.114 \\
\hline Success 4 & 0.847 & 0.013 \\
\hline Success 3 & 0.769 & 0.058 \\
\hline Success 7 & 0.719 & 0.126 \\
\hline Success 6 & 0.702 & -0.047 \\
\hline Success 5 & 0.694 & 0.144 \\
\hline Success 11 & 0.513 & 0.428 \\
\hline Success 12 & 0.495 & 0.323 \\
\hline Success 9 & -0.098 & 0.887 \\
\hline Success 10 & 0.350 & 0.587 \\
\hline Success 8 & 0.036 & 0.378 \\
\hline Cronbach Alpha & 0.936 & 0.712 \\
\hline
\end{tabular}

(1) Loadings greater than 0.35 were considered significant

(2) The items included in the factor analysis are provided in Appendix

Table 1 above illustrates the measuring items of the (dependent variable) PBS. These items were divided into two groups namely Business growth and the EHC. From the table, two items (Success 10; Success 11) were loaded onto both factors (their values were more than 0.35). Instead of deleting the items, the researcher decided to classify the items under a greater factor with the highest loading (Success 10); also for items that make more sense (Success 11). 
Besides, correlation matrix for the dependent variables have shown a correlation of 0.568 ; further approval indicates that oblique rotation should have been useful (Field, 2009). Factor 1 (see Table 1 above) is labelled the EHC with four items such as Success 8, Success 9, Success 10 and Success 11 were used to assess PBS. The study classified these items as highly committed employees with high morale, employees are the most valuable resource and low employees turnover.

Eight supplementary items out of 12 items that were structured to weigh PBS were loaded on factor two and labelled as Business growth (see Table 1) as Success 1, Success 2, Success 3, Success 4, Success 5, Success 6, Success 7 and Success 12. These items were identified to in this study as increased profit, turnover, market share and the competitive position of the business over the past few years. For further evaluation, the internal consistency of the items measuring different factors under investigation were calculated through the Cronbach alpha (Bryman \& Bell, 2007). By means of the Cronbach alpha, the internal consistency was possible to define the average of all the spilt-half reliabilities for a multiple-item scale (Zikmund \& Babin, 2007). There was variation between 0 for no reliability; 1 for maximum reliability (Kent, 2007). Values above 0.7 are considered acceptable and very reliable. The results in Table 1 above pointed that the proposed applicable instrument is reliable for PBS. The PBS have shown enough satisfactory reliability with both factors yielding Cronbach alpha coefficient values more than 0.7 .

Table 2. Verimax rotated factor matrix: Precise constraints

\begin{tabular}{c|c|c|c}
\hline \multirow{2}{*}{ Items } & $\begin{array}{c}\text { Factor 1: } \\
\text { Difficult business } \\
\text { environment }\end{array}$ & $\begin{array}{c}\text { Factor 2: } \\
\text { Lack of support }\end{array}$ & $\begin{array}{c}\text { Factor 3: } \\
\text { Lack of skills }\end{array}$ \\
\hline qb4 & $\mathbf{0 . 8 3 7}$ & 0.126 & -0.051 \\
\hline qb14 & $\mathbf{0 . 7 0 3}$ & 0.203 & 0.083 \\
\hline qb13 & $\mathbf{0 . 6 9 1}$ & 0.108 & -0.089 \\
\hline qb5 & $\mathbf{0 . 6 3 1}$ & 0.139 & -0.044 \\
\hline qb15 & $\mathbf{0 . 5 4 7}$ & 0.225 & 0.013 \\
\hline qb12 & $\mathbf{0 . 3 9 0}$ & 0.186 & -0.061 \\
\hline qb9 & -0.287 & $\mathbf{0 . 5 7 3}$ & -0.018 \\
\hline qb7 & -0.348 & $\mathbf{0 . 5 4 6}$ & -0.155 \\
\hline qb11 & -0.148 & $\mathbf{0 . 5 3 6}$ & -0.220 \\
\hline qb8 & -0.344 & $\mathbf{0 . 4 6 8}$ & -0.114 \\
\hline qb1 & -0.081 & 0.172 & $\mathbf{0 . 5 5 3}$ \\
\hline Cronbach alpha & 0.008 & $\mathbf{0 . 3 7 1}$ & $\mathbf{0 . 4 9 8}$ \\
\hline
\end{tabular}

(1) Loadings greater than 0.35 were considered significant

(2) The items included in the factor analysis are stated in the appendix

Table 2 illustrates individual constraints as one of the two independent variable. This variable is stated in section B of the questionnaire. Analysis of the variable included a Varimax rotation with Kaiser Normalisation which was performed on the principal components of EFA. The Kaiser's criterion was used to extract relevant factors in this study. Only the factors that were valued greater than one were retained (Field, 2009). Field (2009) further indicates that data measuring independent variable with adequacy of 0.776 and BTS yielding a p-value lesser than 0.001 thus indicating a correlation patterns are compact; thus a reliable factor. Data indicated that a total of 12 items have shown sufficient discriminant validity by loading to a sufficient extent. Three items (qb3, qb6 and qb10) were loaded but showed insignificant (below the value of 0.35 ); hence the three items were deleted. Next, the factor matrix of the remaining 12 items (see Table 3 below) were calculated.

According to Davis (2005), in order to apply the factor of extraction criterion, the eigen values must be greater than one. Three factors were extracted using the EFA that explained $41.73 \%$ of the variance prior to rotation. After the process of rotation, the three factors could be identified as the theoretical dimensions; these factors include Difficult business environment, lack of support and Lack of skills. Out of the 12 items, on item loaded greater than one factor (ie value is greater than 0.35 ). The item, qb2, loaded significantly on two factors namely, Lack of support and Lack of skills. These items were not deleted; rather decision was taken to classify them under the factor that yielded the highest factor loading referred to as lack of skills. 
The EFA together with the interpretability of all the factors gives essential evidence of construct validity. The Cronbach alpha coefficient was calculated to assess the internal consistency of the 12 items stated on the measuring instrument. Based on the Cronbach alpha calculations, factor one yielded 0.815; thus it was highly reliable. Further determination by the Cronbach alpha coefficient of the remaining two factors yielded values of 0.695 (rounded off to 0.70 ) and 0.509 respectively. According to Field (2009), research questionnaire designed to measure "knowledge" and "intelligence" should have the Cronbach alpha above the accepted cut-off value of 0.70 . Yet, Field (2009) concedes that the instrument that is designed to measure "attitudes" are exempted; may have lower alphas $(\mathrm{p}<0.70)$ but still accepted as reliable. Drawing from Field (2009), it can be concluded that the applicable measuring instrument for (independent variable) the Individual constraints are reliable and therefore acceptable. Thus, all three factors are therefore included in the statistical analysis.

Table 3. The Principal Axis Factoring factor matrix: Individual constraints

\begin{tabular}{c|c}
\hline Items & $\begin{array}{c}\text { Factor 1 } \\
\text { Individual constraints }\end{array}$ \\
\hline $\mathrm{qd} 9$ & $\mathbf{0 . 7 8 9}$ \\
\hline $\mathrm{qd} 7$ & $\mathbf{0 . 7 6 8}$ \\
\hline $\mathrm{qd} 2$ & $\mathbf{0 . 7 5 3}$ \\
\hline $\mathrm{qd} 3$ & $\mathbf{0 . 7 6}$ \\
\hline $\mathrm{qd} 8$ & $\mathbf{0 . 6 7 2}$ \\
\hline $\mathrm{qd} 6$ & $\mathbf{0 . 6 6 1}$ \\
\hline $\mathrm{qd} 5$ & $\mathbf{0 . 6 3 1}$ \\
\hline $\mathrm{qd} 1$ & $\mathbf{0 . 4 6 5}$ \\
\hline Cronbach alpha & $\mathbf{0 . 8 1 5}$ \\
\hline
\end{tabular}

(1) Loadings greater than 0.35 were considered significant

(2) The items included in the factor analysis are provided in Appendix

In order to assess the (independent variable) individual constraints, the researcher performed an EFA on individual factor 1; individual constraints (see Table 3 above). The Principal Axis factoring extraction technique was applied. Reason for applying this technique is to investigate whether the variable has a unidimensional of multi-dimensional structure. Kaiser's Criterion was used to determine the factors of extraction for retention. Only factors with eigen values greater than one are included in the study (Field, 2009). According to Field (2009), factors with loadings greater than 0.35 are highly significant. From Table 3 above, the factor matrix of EFA in addition to the Principal Axis Factoring extraction investigated the independent variable of individual constraints. This study used the Cronbach alpha coefficient to evaluate the internal consistency of the measuring instrument (Bryman \& Bell, 2007). The internal consistency was possible by computing the averages of all the reliabilities for a multiple-item scale through Cronbach alpha coefficient (Zikmund \& Babin, 2007). According to Kent (2007), the coefficient varies from 0 and 1 for no reliability and maximum reliability respectively. Thus, the results as indicated in Table 5 above propose that the suggested instrument is reliable with all the factors above 0.7 .

\section{Multiple Regression Analysis}

This study seeks to evaluate the effect of precise and individual constraints on PBS. To achieve the stated objective, a multiple regression analysis is performed to test the hypotheses that is formulated through a conceptual framework (see figure 1). The study is structured to determine the extent to which independent variables effect PBS. The outcomes of the analysis is shown in Tables 6, 7, 8 and 9 below. Multiple linear regression analysis is employed to identify relationships between the dependent and independent variables (Wilson, 2010; Rubin, 2009). Cooper and Schindler (2008) add that the multiple linear regression can be used to predict the dependent variables based on several independent or explanatory variables. The factor scores for each entrepreneur was calculated as the averages of all contributory items to relevant factor, automatically replacing missing values by means of substitution. Multiple linear regression analysis was performed to assess whether independent variables (precise and individual constraints) as known in the study exert a significant influence on the dependent variable. PBS is measured in the study by two variables namely Business growth and the EHC to determine the effect on PBS. In addition, separate regression models were calculated. Final results were discussed on the next paragraph below. As discussed in the previous section, only two independent variables with acceptable validity were used. The effect of the two independent variables on the PBS are illustrated in the tables below. 
Table 4. Effect of precise constraints on PBS of Business growth

\begin{tabular}{l|c|c|c|c|c}
\hline \multirow{2}{*}{ Model } & \multicolumn{2}{c|}{ Non-Standardised coefficient } & \multicolumn{2}{c|}{ Standard coefficient } & \multicolumn{2}{c}{ t-value } & P-level \\
\cline { 2 - 7 } & B & Std error & Beta & 8.115 & 0.000 \\
\hline (Constant) & 7.703 & 0.949 & - & -8725 & $0.001^{* *}$ \\
\hline Difficult business environment & -0530 & 0.061 & -0467 & -3.086 & $0.000^{* *}$ \\
\hline Lack of support & -397 & 0.129 & -0.167 & 3.183 & $0.002^{* *}$ \\
\hline Lack of skills & 0.222 & 0.070 & 0.170 & &
\end{tabular}

From Table 4 above, the multiple regression analysis indicates significant negative relationship between independent variables such as Difficult business environment $(-8.725 ; \mathrm{p}<0.001)$, lack of support (-3.086; $\mathrm{p}<0.002)$, lack of skills $(3.183 ; \mathrm{p}<0.002)$. In the light of this, the stated hypothesis that there is significant relationship between the independent variables of Difficult business environment, Lack of support and lack of skills of small businesses growth was accepted. However, as shown from the table, the regression coefficient indicated that Business growth of small businesses is related to variables of a Difficult business environment, lack of support and skills was unaccepted. Given the result of the multiple regression analysis as shown in Table 5 below, there is negative relationship between the independent variables of Difficult business environment (4.767; $p<0.001)$, lack of support (-3.521; $p<0.001)$ and lack of skills (2.095; $p<0.037)$ and dependent variable of $E H C$ of small businesses. The stated hypothesis that there is highly significant relationship between independent variables of Difficult business environment, lack of support and lack of skills and EHC in small businesses is accepted.

Table 5. Effect of precise constraints on PBS of $\boldsymbol{E H C}$

\begin{tabular}{l|c|c|c|c|c}
\hline \multirow{2}{*}{ Model } & \multicolumn{2}{c}{ Non-Standardised coefficient } & \multicolumn{2}{c}{ Standard coefficient } \\
\cline { 2 - 6 } & B & Std error & Beta & t-value & P-level \\
\hline (Constant) & 8.193 & 0.897 & - & 9.132 & 0.000 \\
\hline Difficult business environment & -0.274 & 0.058 & -0.276 & -4.767 & $0.000^{* * *}$ \\
\hline Lack of support & -0.429 & 0.122 & -0.206 & -3.521 & $0.001^{* * *}$ \\
\hline Lack of skills & 0.138 & 0.066 & 0.121 & 2.095 & $0.037^{* * *}$ \\
\hline
\end{tabular}

$\mathrm{R} 2=0.105(* * \mathrm{p}<0.05)$

Table 6 below depicts the multi regression analysis which further shows significant negative relationship between independent variables of individual constraints of small businesses. Results revealed $(-7.192 ; \mathrm{p}<0.001)$ and dependent variable of Business growth of small businesses. Thus, the stated hypothesis that there is a significant relationship between independent variables; Individual constraints of entrepreneurs as well as the dependent variable of the Business growth of small businesses.

Table 6. Effect of individual constraints on PBS of Business growth

\begin{tabular}{l|c|c|c|c|c|}
\hline \multirow{2}{*}{ Model } & \multicolumn{2}{c}{ Non-Standardised coefficient } & \multicolumn{2}{c}{ Standard coefficient } \\
\cline { 2 - 6 } & B & Std error & Beta & t-value & P-level \\
\hline (Constant) & 5.857 & 0.268 & - & 21.867 & 0.000 \\
\hline Individual constraints & -0.415 & 0.058 & -0.395 & -7.192 & 0.000 \\
\hline$R^{2}=0.156\left(^{* *} \times 0.05\right)$
\end{tabular}

$\mathrm{R}^{2}=0.156\left({ }^{* *} \mathrm{p}<0.05\right)$

Table 7. Effect of individual constraints on PBS of Existence of human capital

\begin{tabular}{l|l|l|c|c|c|c}
\hline \multirow{2}{*}{ Model } & \multicolumn{2}{c}{ Non-Standardised coefficient } & \multicolumn{2}{c}{ Standard coefficient } \\
& \multicolumn{2}{c}{ B } & Std error & Beta & t-value & P-level \\
\hline (Constant) & 6.098 & 0.244 & - & 24.974 & 0.000 \\
\hline Individual constraints & -0.249 & 0.053 & -0.272 & -4.724 & $0.000^{* *}$ \\
\hline
\end{tabular}

$\mathrm{R} 2=0.074(* * \mathrm{p}<0.05)$

Practically, as shown in Table 7 above, a percentage of $7.4 \%$ of dependent variables such as Existence of human capital in small businesses is explained through the independent variable of individual constraints as experienced by entrepreneurs. The multi regression analysis as used in Table 7 above revealed a significant negative relationship between the independent variable of individual constraints by entrepreneurs of small businesses. The stated hypothesis 
that there is significant relationship between the independent variable of Individual constraints faced by entrepreneurs of small businesses and the dependent variable $E H C$ is accepted.

\section{CONCLUSION AND RECOMMENDATIONS}

The primary objective of this study was to evaluate the effect of precise and individual constraints on PBS of small businesses. The study outcomes revealed that in general the precise and individual constraints effect on the PBS of small businesses. Put simply, entrepreneurs of small businesses are unable to operate profitable businesses due to constraints. To enhance rural small business operations, a number of recommendations are proposed. Initially, rural entrepreneurs should be encouraged to become active participants in tailor-made initiatives designed to cater for the rural environments. At provincial level, policy development and rural entrepreneurship education and training should be ongoing and be prioritized within rural communities. This would enable smooth integration of rural small businesses into the mainstream economic players. The bulk of South African population is made up of the youth. Future entrepreneurs are likely to emerge from the youth thus providing education and training would encourage immense EHC. Thus, in order to curb individual constraints that hinders most entrepreneurs, it is vital to introduce the youth to entrepreneurship education to offer education and training to the youth at early stages. Through educational initiatives, the growing issues of inadequate information by establishment of rural communication forums (RCFs). The RCFs would assist entrepreneurs to network in several fronts to eliminate constraints including access to valuable financial and marketing information to curtail bribery practices and solve problems of infrastructure (Chowdhury, 2007; Rahman, 2010). The establishment of RCFs provide the necessary exposure to entrepreneurs for insights into vast labour saving technology equipment (Sharma \& Varma, 2008). The establishment of business incubators is recommended to provide access to networks, funding, training and development (De Faoite, Henry, Johnston, Van der Sijde, 2004). Existing knowledge gaps will be filled through the formation of business incubators (Bisseker, 2001). The study recommends rural mentorship programmes (RMPs) to engage rural entrepreneurs in profitable as well as in successful rural entrepreneurial activities. Rural entrepreneurs should be assigned to individual community mentors to offer training.

\section{LIMITATIONS AND FUTURE STUDY}

This study is designed to evaluate the effect of precise and individual constraints on PBS. However, the study was limited only two district municipalities in the Northern Cape Province. Besides, the study was designed to determine the effect of only two constraints of PBS but did not account for the reasons why each constraints impact on PBS. The study applied these constraints as critical factors that impede rural entrepreneurship success. Other factors such as the internal and external environmental business factors were not considered. Given these issues, the findings of this study cannot be generalized to include the Provinces of South Africa. More scientific study is required in the future to understand the reasons behind the effect of the constraints in rural. Such study would be more beneficial to policy makers in rural communities.

\section{CONCLUSION}

This study is designed to determine the effect of two constraints on PBS. Several studies in the past were conducted to determine entrepreneurial challenges. In order to enhance rural entrepreneurial activities and develop small businesses, all forms of constraints need critical examinations through scientific studies. More importantly, rural entrepreneurs require a holistic education and training. Much funding by government must be directed towards rural entrepreneurship education and training. Through these initiatives, rural entrepreneurs would be able to understand the constraints better as most of the constraints are the causes of rampant failure of small businesses. These constraints make it impossible for small businesses to be successful.

\section{AUTHOR BIOGRAPHY}

Albert Tchey Agbenyegah obtained his MBA degree in 2003 and continued to his education with UNISA where he graduated with honors in tax strategy. In 2013, he completed his PhD in Business Administration at the North West University, Potchefstroom. As an emerging researcher, his research passion include rural entrepreneurship and small businesses, technology education, business management and strategic management. Email: alberta@dut.ac.za 


\section{REFERENCES}

Abor, J. \& Quartey, P. (2010). Issues in SME development in Ghana and South Africa. International Research Journal of Finance and Economics, (39), 218-228.

Ackah, J., \& Vuvor, J. (2011). The challenges faced by small \& medium enterprises (SMEs) in obtaining credit in Ghana. Blekinge School of Management, An MBA Thesis (unpublished).

Abdul, M. A., Omar, N. H. \& Yee, L. K. (2012). Critical success factors of entrepreneurs in business. Journal of Social Sciences and Humanities, 7(1), 34-45.

Ahmad, Z.S. \& Xavier, S.R. (2012). Entrepreneurial environments and growth: Evidence from Malaysia GEM data. Journal of Chinese Entrepreneurship, 4(1), 50-69

Alam, S. S., Jani, M. F. M. \& Omar, N. A. (2011). An empirical study of success factors of women entrepreneurs in southern region in Malaysia. International Journal of Economics and Finance, 3(2), 166-175.

Ardagna, S. \& Lusardi, A. (2009). Heterogeneity in the effect of regulation on entrepreneurship and entry size. NBER WP 15510 , NBER, Cambridge.

Bates, T., Jackson, W. E. \& Johnson, J. H. (2007). Advancing research on minority entrepreneurship. Annals of the American Academy of Political and Social Science, (613), 10-17.

Baumgartner, D., Schulz, T. \& Seidl, I. (2013). Quantifying entrepreneurship and its impact on local economic performance: A spatial assessment in rural Switzerland. Entrepreneurship \& Regional Development, 25(3-4), 222-250.

Benzing, C., Chu, H. M. \& Kara, O. (2009). Entrepreneurs in Turkey: A factor analysis of motivations success factors and problems. Journal of Small Business Management, 47(1), 58-91.

Beer, S. (2004). 'Peripherally and information flow in remote island areas of Scotland'; Paper presented at Europe at the Margins: EU Regional Policy, Peripherally and Rurality, Angers, France.

Bigsten, A. \& Gebreeyesus, M. (2007). 'The small, the young and the productive: Determinants of manufacturing firm growth in Ethiopia. Economic Development and Cultural Change, 55(4), 813-838.

Bisseker, C. (2001). First AIDS risk cover for companies. Financial Mail. August 2001. www.bdfm.org

Blau, J. (2009). New spurs for Europe's small firms. Research Technology Management, 52(3), 5-7.

Blumberg, B., Cooper, D. R. \& Schindler, P. S. (2011). Business Research Methods, $3^{\text {rd }}$ European Edition. London, McGraw Hill.

Bosma, J., Acs, Z. J., Autio, E., Conduras, A. \& Levie, J. (2009). Global entrepreneurship monitor. Executive report. Boston, MA: Babson College.

Bowler, A., Dawood, M.S. \& Page, S. (2007). Entrepreneurship and Small business Management. Pretoria: Juta \& Co. Ltd.

Bryman, A. \& Bell, E. 2007. Business Research Methods. ( $2^{\text {nd }}$ Edition.). New York. N.Y. Oxford University Press.

Cant, M., Gerber-Nel, C., Nel, D. \& Kotze, T. (2012). Marketing Research, Claremont: New Africa Education.

Cardon, S. M., Stevens, C.E. \& Potter, D.R. (2009). Misfortunes or mistakes? Cultural sensing of entrepreneurial failure. Journal of Business Venturing, 2 (1), 79-92.

Chowdhury, M. S. (2007). Overcoming entrepreneurship development constraints: the case of Bangladesh. Journal of Enterprising Communities: People and Places in the Global Economy, 1(3), 240-251.

Cooper, D.R. \& Schindler, P.S. (2008). Marketing research. New York, NY: McGraw-Hill.

Davis, D. (2005). Business research for decision-making. (6 ed). Belmont, C.A: Thomson Learning.

Davidsson, P., Steffens, P. \& Fitzsimmons, J. (2009). Growing profitable of growing from profits. Journal of Business Venturing, 24(4), 373-387.

De Faoite, D., Henry, C., Johnston, K. \& Van Der Sijde, P. (2004). Education and training for entrepreneurs: A consideration of initiatives in Ireland and The Netherlands. Education and Training, 45(8/9), 430-438.

Du Plessis, S. A. \& Smit, B. W. (2004). Stabilisation policy in South Africa. Stellenbosch, Paper presented at the 8th annual conference for econometric modelling in Africa, Stellenbosch. July 2003.

Dyllick, T. \& Hockerts, K. (2002). Beyond the business case for corporate sustainability. Business Strategy and the Environment, $11(2), 130-141$.

Ehlers, T. \& Lazenby, K. (2007). Strategic management: South Africa concepts and cases. Pretoria: Van Schaik.

Ellis, S.M. \& Steyn, H.S. (2006). Practical significance (effect sizes) versus or in combination with statistical significance @values. Management Dynamics, 12(4), 51-53.

Fatoki, O. \& Chindoga, L. (2011). An investigation into the obstacles of youth entrepreneurship in South Africa. International Business Research, 4(2), 161-169.

Fatoki, O. \& Van Aardt Smit, A. (2011). Constraints to credit access by new SMEs in South Africa: A supply-side analysis. African Journal of Business Management, 5(4), 1413-1425.

Faraji, S., Hassanali, B., Seyed, A., Sajasi, G. H., Sadeghlou, T. \& Shahdadi, K. A. A. (2011). Priority scheduling of entrepreneurship development in rural areas by Promati technique, Journal of Hum.Geo. Res., (75), 53-68.

Field, A. (2009). Discovering statistics using SPSS. 3rd ed. London: SAGE.

Fonseca, R., Michand, P. \& Sopraseuth, T. (2007). Entrepreneurship, wealth, liquidity constructs and start-up costs. DP 2874. Bonn: Institute for the study of labour 
Gill, A. \& Biger, N. (2012). Barriers to small business growth in Canada. Journal of Small Business and Enterprise Development, 19(4), 656-668.

Gem (2010). Global entrepreneurship monitor. South Africa Report. Cape Town: GEM

Gürbüz G. \& Aykol S. (2009). Entrepreneurial management, entrepreneurial orientation and Turkish small firm growth. Management Research News, 32(4), 321- 336.

Hatega, L (2007): SME development in Uganda, Private Sector Foundation Uganda, Kampala.

Hair, J., Black, B.B., Anderson, R. \& Tatham, R. (2006). Multivariate data analysis. 6th ed. Upper Saddle River NJ: PrenticeHall.

Harrison, R. L. \& Reilly, T. M. (2011). Mixed methods designs in marketing research. Qualitative Market Research: $A n$ International Journal, 14(1), 7-26.

Herrington, M., Kew, J., \& Kew, P. (2010). Global entrepreneurship monitor (GEM) South African Report 2010. Cape Town: University of Cape, Graduate school of business.

Hussain, D. \& Windsperger, J. (2010). Multi-unit ownership strategy in franchising: Development of an integrated model. Journal of Marketing Channels, 17(1), 3-31.

IFC (2006). Small and Medium Enterprise Department, Background Note on Micro, Small and Medium enterprise database, World Bank, Washington

Investment Climate Survey (2004). South African Investment Climate Survey. www.worldbank.org Date of access: 18 Feb 2016

Ishak, S., Omar, A.R.C. \& Ahmad, A. (2012). Business venture of the poor: performance and problems, International Journal of Business and Social Science, 3(16), 165-177.

Karpak, B. \& Topcu, I. (2010). Small, medium manufacturing enterprises in Turkey: an analytical network process frame work for prioritizing factors affecting success. Journal of Production Economics, 125(1), 60-70.

Kauffmann, C. (2005). Financing SMEs in Africa, OECD Development Centre, Policy Insight nr 7, OECD, Paris.

Karimi, S., Chizari, M., Biemans, H. J. A., \& Mulder, M. (2010). Entrepreneurship education in Iranian higher education: The current state and challenges. European Journal of Scientific Research, 48(1), 35 - 50.

Kent, R. (2007). Marketing research approaches, methods, and applications in Europe. London: Thomson Learning.

Kongolo, M. (2010). Job creation versus job shedding and the role of SMEs in economic development. African Journal of Business Management, 4(11), 2288-2295.

Kwong, C., Thompson, P., \& Jones-Evans, D. (2012). Differences in perceptions of access to finance between potential male and female entrepreneurs.

Lan, Q. \& Wu, S. (2010). An empirical study of entrepreneurial orientation and degree of internationalisation of small and medium-sized Chinese manufacturing enterprises. Journal of Chinese Entrepreneurship, 2(1), 53-75.

Lind, P. (2009c). The SME in a changing world-opportunities and threats; lecture in SME management in a global context Autumn 2009, 17 September, Gotland University Visby.

Makhbul, Z. M. \& Hasun, F. M. (2011). Entrepreneurial success: An exploratory study among entrepreneurs. International Journal of Business and Management, 6(1), 116-125.

Martin, G. \& Staines, H. (2008). Managerial competencies in small firm. [Online] Available: http://www.emraldinsight.com/insight/viewcontentitem.do?contenttype. Date access: 20 Feb 2015

Masalira, S. \& Msweli, P. (2013). Book of Proceedings, 1484-1494. Varazdin: Varazdin Development and Entrepreneurship Agency (VADEA). Date accessed: Apr 5, 2016. The role of SMEs in national economies: The case of South Africa. Economic and Social Development

Matlay, H., \& Carey, C. (2007). Entrepreneurship education in the UK: A longitudinal perspective. Journal of Small Business and Enterprise Development, 14(2), 252-263.

Mead, D.C. \& Lieldholm, C. (1998). The dynamics of micro and small enterprises in developing countries. In World Development, 26(1), 61-74.

Nabi, G. \& Linan, F. (2011). Graduate entrepreneurship in the developing world: Intentions, education and development. Education and Training, 53(5), 325-334.

National Small Business Act. See South Africa.

Ngassam, E.K., Kandie, W., Nkaelang, B. \& Modiba, F. (2009). Proceedings of IST-Africa 2009 Conference, May 6-8, Uganda, Kampala: Towards an e-model for the enhancement of service rendering by SMMEs supporting agencies in South Africa.

Nichter, S. \& Goldmark, L. (2009). Small firm growth in developing countries. World Development, 37(9),1453-1464.

OECD. (2006). Promoting Entrepreneurship and Innovative SMEs in a Global Economy: Towards a more Responsible and Inclusive Globalization. OECD

Ooghe, H. \& De Prijcker, S. (2008). Failure processes and causes of company bankruptcy: A typology. Management Decision, 46(2), 223-242.

Parker, S. (2007). Law and the economics of entrepreneurship. Comparative Labour Law and Policy Journal, (28), 695-716.

Rahman, M., (2010). Barriers for women entrepreneurs in Bangladesh. BRAC. Development Institute (BDI). Aug: 0837.

Rodriguez, G. (2009). Three indicators of a successful business. www.powerhomebiz.com/vol15/3indicators.htm 07/02/2015

Rogoff, E.G., Lee, M.S., \& Suh, D.C. (2004). Who done it? Attributions by entrepreneurs and experts of the factors that cause and impede small business success. Journal of Small Business Management, 42(4), 364-376. 
Rubin, D. (2009). Multiple imputation for nonresponse in surveys. New York: John Wiley \& Sons.

Rwigema, H. \& Venter, R. (2008). Advanced entrepreneurship. 2nd ed. Cape Town: Oxford University.

Sharma, P. \& Varma, S. K. (2008). Woman empowerment through entrepreneurial activities of self-help groups. Journal of Asian and African Studies, 8(1), 46-51.

Silverman, R. M. \& Patterson, K. L. (2011). The effects of perceived funding trends on non-profit advocacy: A national survey of non-profit advocacy organisations in the United States, International Journal of Public Sector Management, 24(5), 435-451.

Skuras, D., Meccheri, N., Moreira, M. B., Rosell, J. \& Stathopoulou, S. (2005). Entrepreneurial human capital accumulation and the growth of rural businesses: a four-country survey in mountainous and lagging areas of the European Union. Journal of Rural Studies, 21(1), 67-79.

South Africa Information. (2010). Incentives for exporters. http://www.southafrica.info/business/trade/export/incentives.htm. Date of access: 5 July 2010.

StatSoft, Inc. (2010). Statistica Data Analysis Software System. Release 10. (www.stasoft.com).

Stathopoulou, S., Psaltopoulos, D. \& Skurus, J. (2004). Rural entrepreneurship a research framework and agenda. Intenational Journal of Entrepreneurial Behaviour and Research, 10(6), 404-425.

Taormina, R. J. \& Lao, S. K. M. (2007). Measuring Chinese entrepreneurial motivation, personality and environmental influences. International Journal of Entrepreneurial Behaviour \& Research, 13(4), 200-221.

Timm, S. (2011). How South Africa can boost support to small businesses: Lessons from Brazil and India. Trade and Industrial policy strategies (TIPS). South Africa.

Townsend, D.M., Busenitz, L.W. \& Arthurs, J. I. (2010). To start or not to start: Outcome and ability expectations in the decision to start a new venture. Journal of Business Venturing, (25), 192-202.

Van Praag, C.M. (2003). Business survival and success of young small business owners. Small Business Economics, (21), 1-17.

Wenneberg, K., Wiklund, J., Detienne, D.R. \& Cardon, S.M. (2010). Reconceptualizing entrepreneurial exit: Divergent exit routes and their drivers. Journal of Business Venturing, (25), 361-375.

Wilson, J. (2010). Essentials of business research: A guide to doing your research project. Sage Publications.

Woodward, D., Rolfe, R., Ligthelm, A. \& Gruimaraes, P. (2011). The validity of informal microenterprise in South Africa. Journal of Developmental Entrepreneurship, 16(1), 65-86.

$\mathrm{Xu}$, Y. \& Van der Heijden, B. (2005). The employee factor in the service-profit chain framework: A study among service employees working within a leading Chinese securities firm. Journal of International Consumer Marketing, 18(1), 137155 .

Zikmund, W.G. \& Babin, B.J. (2007). Exploring marketing research. 9th ed. Mason: Thomson Learning. 


\section{NOTES}

